\title{
Clay Fraction Distribution in the Sediments of the Senegal River Estuary after the Diama (Senegal) Dam Construction
}

\author{
Ndiaye, Ada ${ }^{1}$, Diouf, Bachir ${ }^{1}$, Diara, Mariline ${ }^{1}$ and Giresse, Pierre ${ }^{2}$ \\ 1. Département de Géologie, Faculté des Sciences et Techniques,Université Cheikh Anta Diop, Dakar - Sénégal \\ 2. Centre de Formation et de Recherche sur les Environnements Méditerranéens (CEFREM) Université de Perpignan Via Domitia - \\ France
}

\begin{abstract}
Clay fraction contents distribution in the Senegal River estuary after the building of the anti-salt Diama dam has shown that upstream sediments are very muddy. Clay fraction content is as high as $60 \%$ of sediments in the middle of the channel with a pronounced downstream decreasing trend on the banks comparing to the contents in the middle of the channel. Towards the river mouth, the fine fraction tends to disappear leading to a shelly sand sediment type essentially. During low water period, clay fraction contents increase particularly at the vicinity of the dam reservoir. In the estuarine reach, downstream the dam, this increasing trend during the low water stage is particularly marked in the middle of the channel. The clay mineral assemblage shows that kaolinite and smectite are the main components, whereas interlayered illite-smectite and illite are minor constituents. The upstream-downstream profile shows a decrease in kaolinite content although it remains the dominant constituent. Floating clay minerals (smectite and illite-smectite) concentrate rather in the middle of the channel and on the right bank where the water depth is higher. According to seasonal variations, the distribution of these clay minerals often follows the concentration of the entire clay fraction; their contents increase during low water stage period. This hydrodynamics sorting of floating minerals, evident in the up-dam zone, tends to disappear in the eastern reach between Diama dam and the mouth. Clay minerals assemblage shows, through the time, a rather homogeneous composition which does not seem to be altered by the seasonal fluctuations.
\end{abstract}

Key words: Senegal river, diama dam, clays, sedimentology, mineralogy.

\section{Introduction}

The change of the hydrological flow regime of the Senegal River induced by the Diama anti-salt dam building in November 1985 has caused a change in the sedimentation process in the estuarine zone. In this regard, numerous studies were realized after this event [1-3]. Prior to the Dam building, pioneering works of Refs. [4-6], were carried out on lower valley and delta sediments using cores. Other works were realized on the sediments mouth offshore [7], on suspended sediments [8] and on alluvial soils [9]. This latter showed that in the mangrove swamp sediments, kaolinite and smectite are the major mineral

Corresponding author: Ndiaye, Ada., Doctorate of the 3rd cycle/Assistant, research field: sedimentology. constituents representing more than $90 \%$ of the clay fraction with the remaining being made of illite and interlayered illite-smectite. A similar composition was found in suspended materials. However, works of the [9] on the alluvial deposits in the valley allowed differentiating sectors of different mineralogical compositions with predominance of kaolinite in the lower valley and the delta whereas in tidal area, smectite and illite-smectite dominate. Studies carried out on suspended particles by Kane just after the building of the dam showed clay sediment compositions (kaolinite, smectite, illite and illite-smectite) were similar to those found prior to the dam implementation [2]. This study aims to investigate the clay fraction distribution processes in 
the alluvial sediments derived by changes in hydro-sedimentary conditions inferred by the Diama dam. It focuses mainly on modifications of fine particles accumulation as well as on change in clay fraction types and assemblage within the context of anthropogenic estuary of Senegal.

\section{Study Area}

\subsection{Geological Setting}

The Senegal River watershed covers Precambrian and Paleozoic formations in its upper valley then Mesozoic to Cenozoïc formations of the Senegal-Mauritanian sedimentary basin in the middle valley and delta zone. In these latter regions, Secondary and Tertiary formations are known through drillings [10]. Marine transgressions during the Jurassic period deposited clays, marls and neretic limestones, while Cretaceous period is marked by the clastic Maastrichtian deposits. This latter formation extends beneath the valley as far as Kaedi region [11].

Paleocene deposits are less represented; its transgressive formations are composed of marls, calcareous sandstones and shelly limestones. Lower Eocene deposits are essentially represented by biochemical facies, characterized by alternating lithofacies from clays to limestones. These formations are partially eroded at the vicinity of the Guiers Lake anticline [12]. At Bogue locality, yellow layered clays characterize the middle Eocene period. Minerals inherited from these clays (attapulgite and sepiolite) made up of are frequently found within delta deposits in small amounts [6]. Clay formations of the middle Eocene are covered by ferruginous crust derived from dismantling of Miocene "Salum Formation" (former “Continental Terminal”) [13]. Miocene formations extend in the whole Senegal-Mauritanian sedimentary basin with kaolinic clay cemented sandstones [5]. This author pointed out that ancient marine Pleistocene deposits are characterized by kaolonite, smectite, and to a lesser extent illite probably derived from Salum Formation.
In the delta zone, smectite and interstratified illite-smectite occur in muds as well as in muddy sands and this independently to hydrodynamic environment conditions [6]. Kalck found that the downstream increase trend of smectite is associated with detritic sedimentation derived from marine fluxes inside the estuary; smectite is mainly ferriferous clay of beidellite type. It's content increase off the mouth with regard to kaolinite and illite [4, 7]. Kalck also showed that degraded kaolinite clays (fire-clay type) are inherited from the Salum formation.

\subsection{Hydrological and Hydrodynamic Context}

The Senegal River flows through about $1,800 \mathrm{~km}$ long and its watershed is constituted of three main zones: the upper basin, the valley and, downstream from Richard-Toll toward the ocean, the delta zone. In its delta (Fig. 1), Senegal River extends to a large domain where flow occurs in numerous effluents and flooded depressions, before joining the ocean through a unique channel.

The anti-salt Diama dam built $50 \mathrm{~km}$ upstream the river mouth (Fig. 1) operated since November 1985; it regulates flow to the ocean and preserves a constant water level in the upstream area. Dam outlets are closed from the end of November of June (low level water period) and opened from July to November (period of floods). Downstream the dam, during the releases of water, stream flow becomes hardly perceptible and the speed of the ebb tide becomes higher near the surface than near the bottom [14]. In the same time, differences occur in fine suspended materials contents which are $740 \mathrm{mg} / \mathrm{l}$ and $400 \mathrm{mg} / \mathrm{l}$ in the upstream zone and the downstream side respectively [15]. During low level water, closure of the dam outlets prevent seawater intrusion upstream and the suspended sediments contents lower down to $20 \mathrm{mg} / \mathrm{l}$ due to deposition in the lower reach. However, the suspended fine particles are slightly higher in the upstream dam zone. 


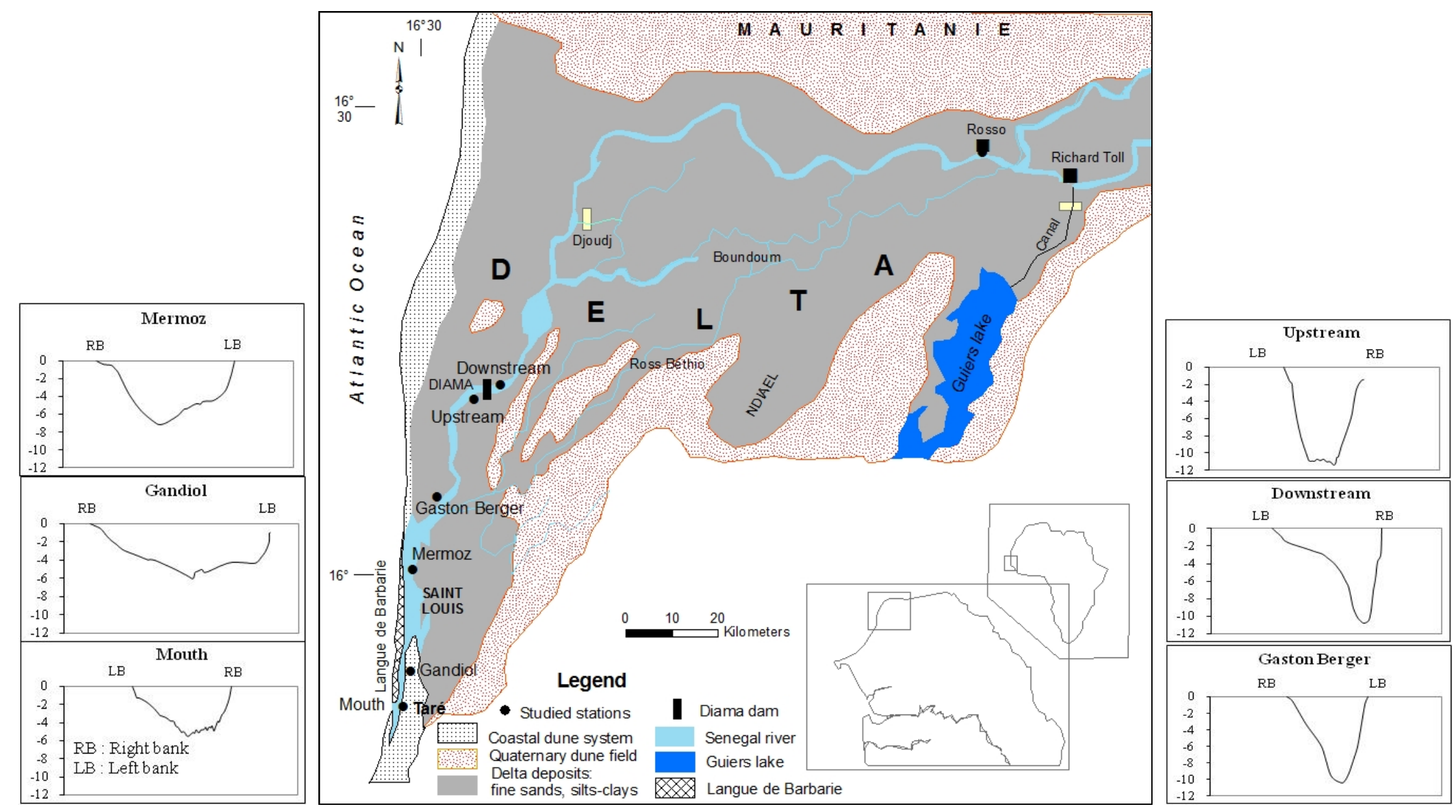

Fig. 1 Location of the studied area and bathymetrical evolution. 


\section{Sampling and Analytical Methods}

Sediment samples were collected using a dredging tool on a three points transect (left bank, middle and right bank) at six sites between the river mouth and the upstream dam (Fig. 1). The sampling campaigns were carried out on a yearly basis during high and low water periods. For each sample, fine fraction was separated from coarse fraction using a $50 \mu \mathrm{m}$ sieve, then pelitic index was calculated. Sedimentological and mineralogical investigations were carried out at the Marine Geo-Environment Research Laboratory at Perpignan University. Sedigraph 5100 was used to calculate $<2 \mu \mathrm{m} /<50 \mu \mathrm{m}$ ratio and then to report clay content to the total sediment.

$\mathrm{X}$-ray diffractometry method was used to determine clay mineral types. Prior to that, clay constituent $(<2$ $\mu \mathrm{m})$ was extracted using ultracentrifugation, and then few drops of suspension solution were placed onto thin section glass support before drying. For each sample, X-ray diffractometry analysis was carried out for an untreated thin section and an ethylene glycol treated preparation in order to better identify swelling clays. The relative abundance of clay minerals was semi-quantitatively estimated by measuring surface peak areas. Percentage of each mineral was computed using ratio of the mineral peak surface to the total peak surface of all minerals.

\section{Results}

\subsection{Spatio-Temporal Distribution of the Clay Fraction $(<2 \mu \mathrm{m})$}

Clay fraction distribution in the Senegal River estuary shows that upstream the Diama dam, sediments are highly muddy with the highest clay content within the transversal section whatever the point under consideration. In the middle channel, contents as high as 53\% to $60 \%$, 30\%-38\% in the right bank, while in left bank values are less than 20\% (Fig. 2). At the downstream vicinity of the dam (Figs. 2 and 3) , clay contents compared with concentrations in the upstream, diminish slightly to about 50\%-55\% in the middle of the channel; this lowering is more marked in the right and left banks where measured values are 10\%-20\% (Fig. 3). Downstream, near the river mouth, clay contents continue to decrease. Clay fraction tends to disappear in the river mouth where shelly sand is the main constituent. Transects in the estuary show, that clay contents are higher in the middle channel than in the banks (Fig. 2).

According to the seasonal river regime, clay contents increase upstream the dam during low water period; this increase observed in all transects is from $30 \%$ to $38 \%$ in the right bank, $53 \%$ to $60 \%$ in the middle channel and 3\% to 23\% in the left bank (Fig. 2 and Table 1). At the dam downstream vicinity, clay content variations are less marked than upstream (Fig. 3 ); while in the middle channel and right bank, clay contents slightly decrease during low stage water period. Toward the river mouth, increase in clay contents observed on the transverse profile (Fig. 2) is particularly marked in the middle channel. However, some slight changes occur in the banks where there is mostly a decrease in clay content.

\subsection{Clay Minerals Distribution}

Distribution of clay minerals shows that kaolinite and smectite constitute the dominant species (80\%) associated to a lesser extent by interstratified illite-smectite and illite (Fig. 4). Upstream the dam, kaolinite is the most represented mineral (40\%-50\%) in all transects and periods; followed by smectite and interstratified illite-smectite. The highest content of these latter minerals occurs in the channel middle (Table 2). Toward the river mouth, kaolinite is still the dominant species despite its contents are reduced in the banks. The longitudinal profiles (upstream-downstream) show opposition in distribution patterns of most floating minerals (smectite and illite-smectite): when one increases the other decreases, and vice versa. Upstream Diama dam, during the high water and low water stage, the 


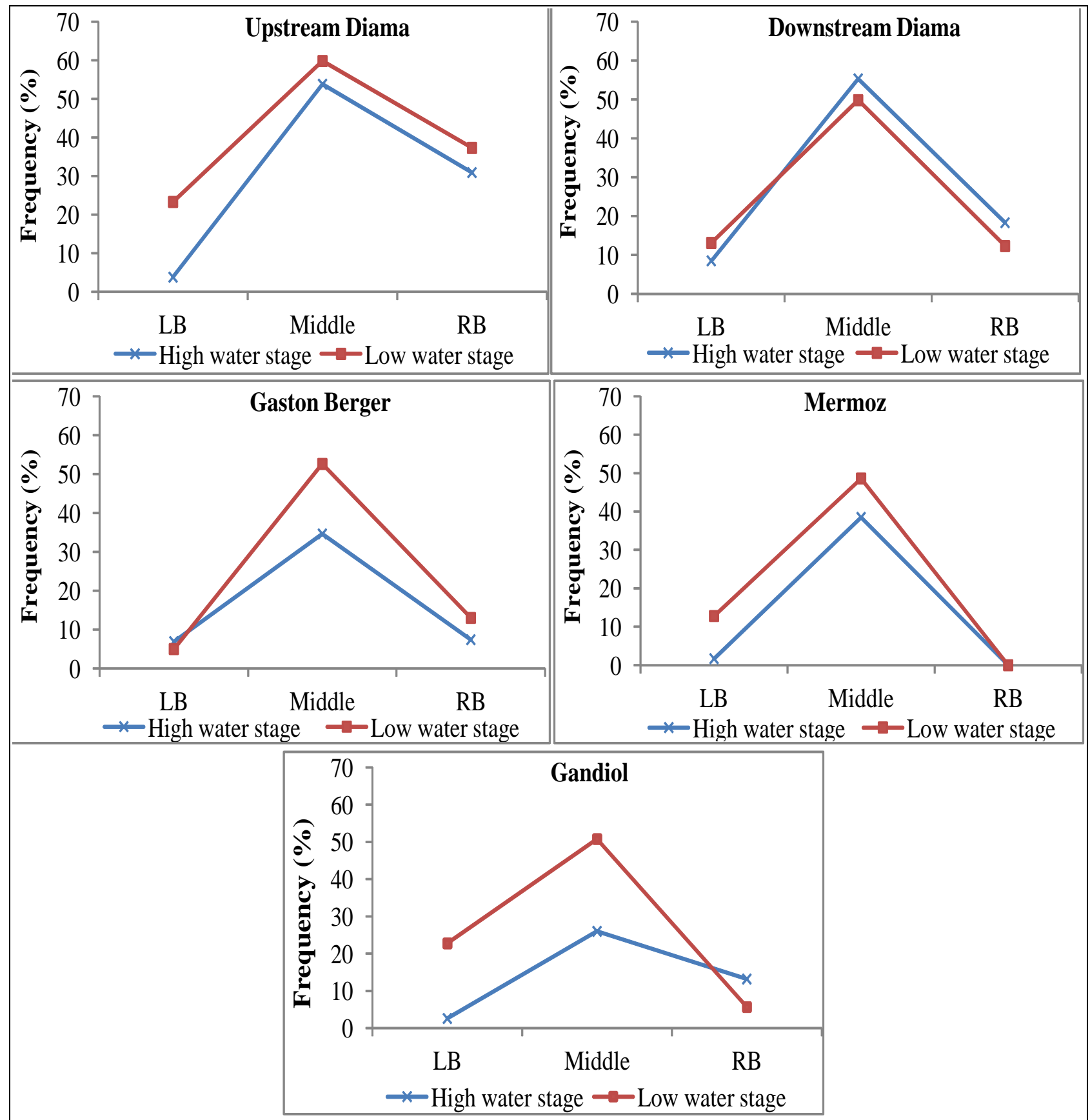

Fig. 2 Clay contents distribution according to the transverse profiles.

interstratified I-Sm are more abundant in the middle of the river channel (up to 30\%) than on the banks. Downstream, banks present higher levels than the channel during high water stage recession (Tables 3 and 4). During this period, values decrease linearly from the right bank to the left bank.

Depending on seasonal variations, upstream of the dam, distribution of most floating minerals (smectite and illite-smectite) often follows the concentration of the clay fraction. These minerals are highly represented in the channel middle and in the right bank and their content increases during low water period (Fig. 5). Smectite is an exception during the flood with higher values on the left bank. Floating clay minerals appear to preferentially distribute in mid-channel and right bank. It appears quite clearly in 

Diama (Senegal) Dam Construction
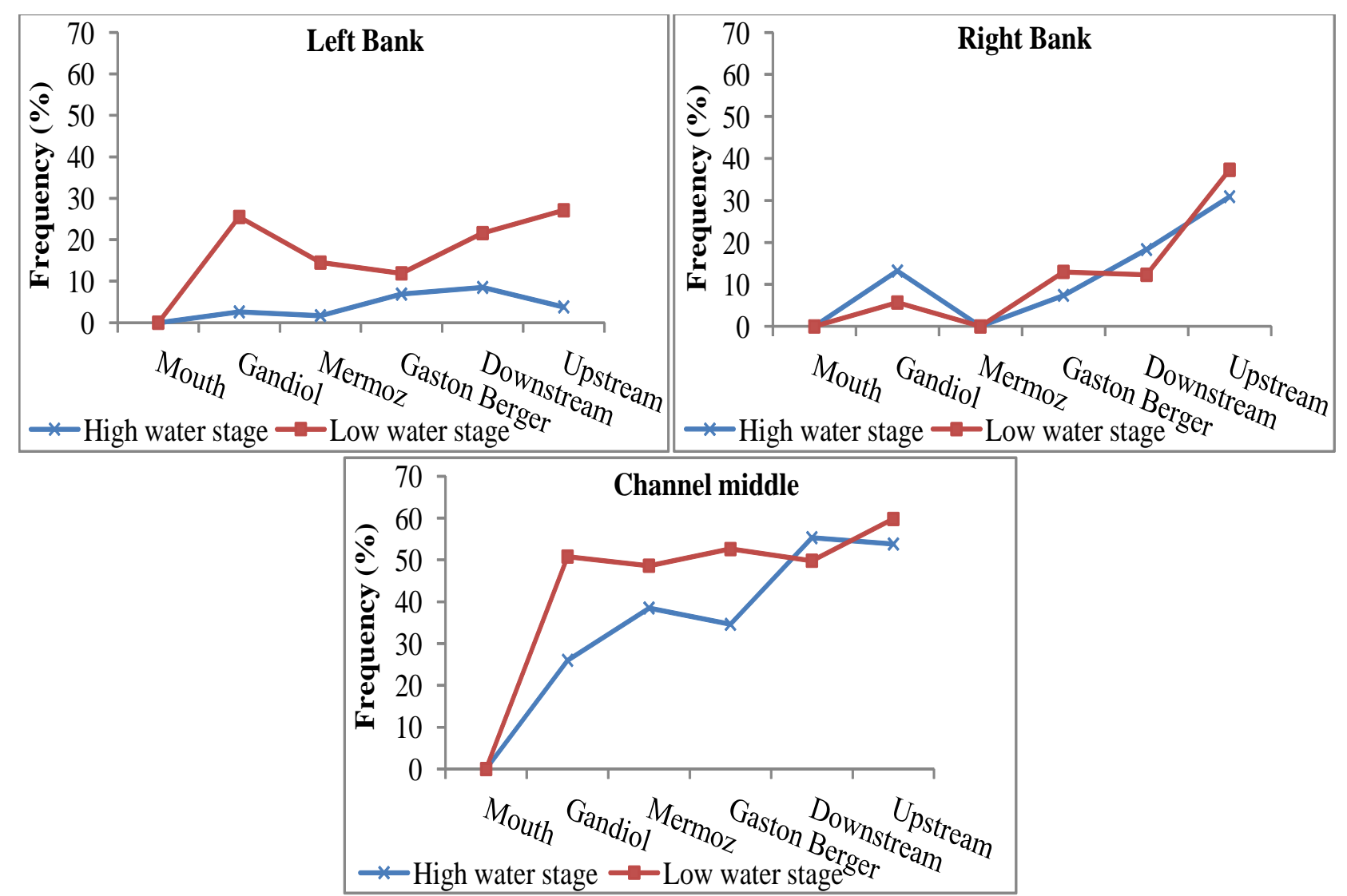

Fig. 3 Longitudinal variations of clay content.

Table 1 Clays contents (\%) variations according the seasonal river regime.

\begin{tabular}{|l|l|c|c|}
\hline & Sites & High water stage & Low water stage \\
\hline \multirow{5}{*}{ Left bank } & Upstream & 3.8 & 23.3 \\
\cline { 2 - 4 } & Downstream & 8.5 & 13.1 \\
\cline { 2 - 4 } & Gaston Berger & 6.9 & 5 \\
\cline { 2 - 4 } & Mermoz & 1.7 & 12.8 \\
\cline { 2 - 4 } & Gandiol & 2.6 & 22.9 \\
\cline { 2 - 4 } & Mouth & 0 & 0 \\
\hline \multirow{5}{*}{ Channel middle } & Upstream & 53.8 & 59.8 \\
\cline { 2 - 4 } & Downstream & 55.3 & 49.8 \\
\cline { 2 - 4 } & Gaston Berger & 34.6 & 52.6 \\
\cline { 2 - 4 } & Mermoz & 38.5 & 48.6 \\
\cline { 2 - 4 } & Gandiol & 26 & 50.8 \\
\cline { 2 - 4 } & Mouth & 0 & 0 \\
\hline \multirow{5}{*}{ Right bank } & Upstream & 30.9 & 12.3 \\
\cline { 2 - 4 } & Downstream & 18.3 & 13 \\
\cline { 2 - 4 } & Gaston Berger & 7.4 & 0 \\
\cline { 2 - 4 } & Mermoz & 0 & 0.7 \\
\cline { 2 - 4 } & Gandiol & 13.2 & 0 \\
\cline { 2 - 4 } & Mouth & 0 & \\
\hline
\end{tabular}


Clay Fraction Distribution in the Sediments of the Senegal River Estuary after the Diama (Senegal) Dam Construction

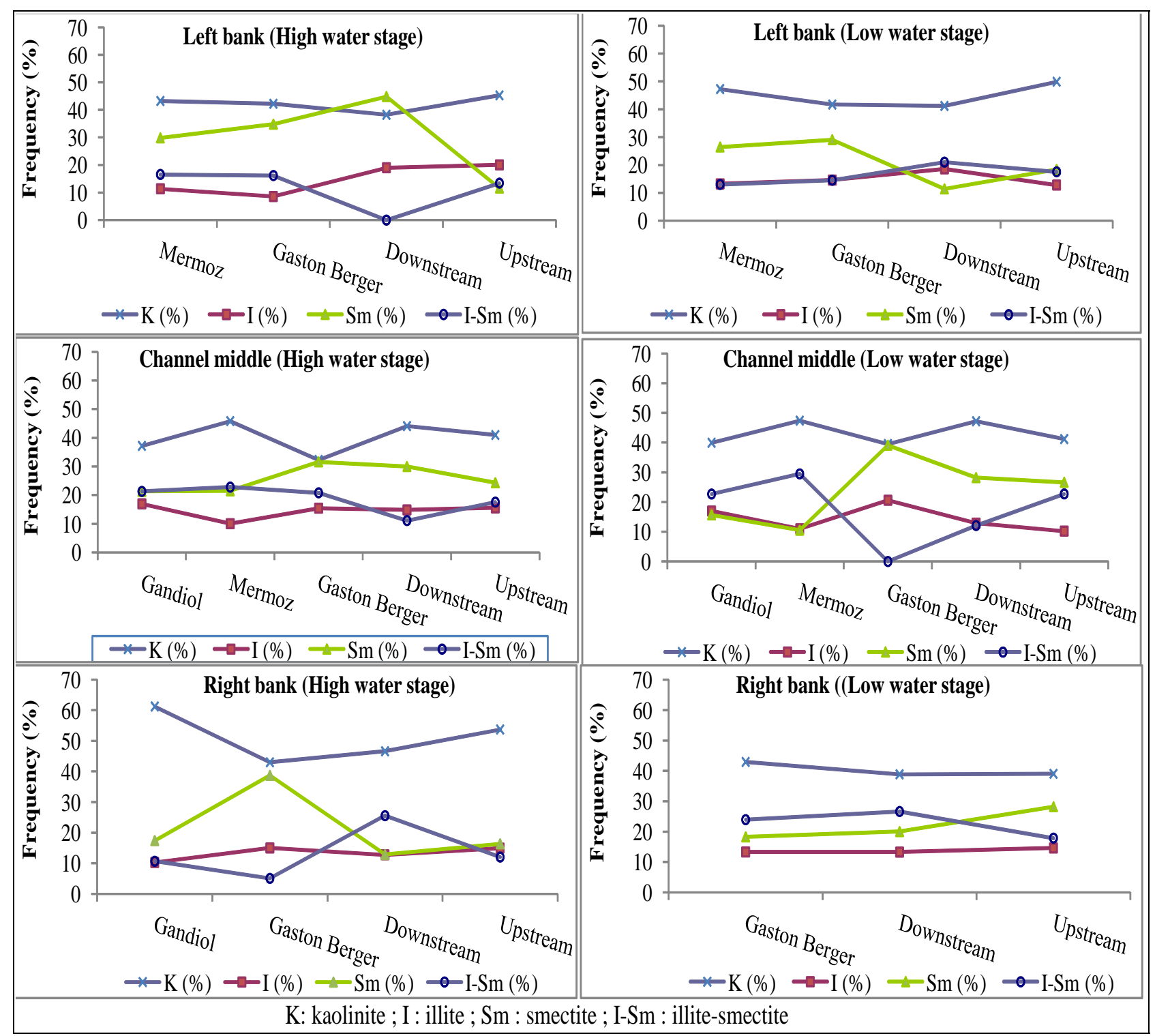

Fig. 4 Longitudinal variations of clay minerals.

Table 2 Clay minerals variations in the channel middle.

\begin{tabular}{|l|l|c|c|c|c|}
\hline River Regime & Sites & K (\%) & Sm (\%) & I (\%) & I-Sm (\%) \\
\hline \multirow{4}{*}{ High water stage } & Upstream & 40.99 & 24.34 & 15.37 & 17.57 \\
\cline { 2 - 6 } & Downstream & 44.08 & 29.99 & 14.85 & 11.14 \\
\cline { 2 - 6 } & Gaston Berger & 32.29 & 31.6 & 15.45 & 20.82 \\
\cline { 2 - 6 } & Mermoz & 45.83 & 21.49 & 10.04 & 22.81 \\
\cline { 2 - 6 } & Gandiol & 37.18 & 21.31 & 16.96 & 21.31 \\
\hline \multirow{4}{*}{ Low water stage } & Upstream & 41.21 & 26.63 & 10.22 & 22.74 \\
\cline { 2 - 6 } & Downstream & 47.18 & 28.23 & 12.92 & 12.1 \\
\cline { 2 - 6 } & Gaston Berger & 39.54 & 39.12 & 20.61 & 0 \\
\cline { 2 - 6 } & Mermoz & 47.39 & 10.55 & 10.98 & 29.48 \\
\cline { 2 - 6 } & Gandiol & 39.97 & 15.68 & 16.97 & 22.69 \\
\hline
\end{tabular}



Diama (Senegal) Dam Construction

Table 3 Clay minerals variations in the left bank.

\begin{tabular}{|l|l|c|c|c|c|}
\hline River Regime & Sites & K (\%) & Sm (\%) & I (\%) & I-Sm (\%) \\
\hline \multirow{3}{*}{ High water stage } & Upstream & 45.28 & 11.65 & 20.07 & 13.43 \\
\cline { 2 - 6 } & Downstream & 38.23 & 44.86 & 19.01 & 0 \\
\cline { 2 - 6 } & Gaston Berger & 42.24 & 34.83 & 8.57 & 16.17 \\
\cline { 2 - 6 } & Mermoz & 43.25 & 29.84 & 11.36 & 16.58 \\
\hline \multirow{3}{*}{ Low water stage } & Upstream & 49.89 & 18.43 & 12.84 & 17.57 \\
\cline { 2 - 6 } & Downstream & 41.21 & 11.43 & 18.63 & 21.04 \\
\cline { 2 - 6 } & Gaston Berger & 41.71 & 29.08 & 14.62 & 14.54 \\
\cline { 2 - 6 } & Mermoz & 47.26 & 26.47 & 13.23 & 13.02 \\
\hline
\end{tabular}

Table 4 Clay minerals variations in the right bank.

\begin{tabular}{|l|l|c|c|c|c|}
\hline River Regime & Sites & K (\%) & Sm (\%) & I (\%) & I-Sm (\%) \\
\hline \multirow{4}{*}{ High water stage } & Upstream & 53.69 & 16.37 & 14.978 & 12.04 \\
\cline { 2 - 6 } & Downstream & 46.6 & 12.89 & 12.76 & 25.56 \\
\cline { 2 - 6 } & Gaston Berger & 42.99 & 38.73 & 15.03 & 5.09 \\
\cline { 2 - 6 } & Gandiol & 61.2 & 17.42 & 10.27 & 10.68 \\
\hline \multirow{3}{*}{ Low water stage } & Upstream & 39.05 & 28.23 & 14.61 & 17.88 \\
\cline { 2 - 6 } & Downstream & 38.87 & 20.03 & 13.27 & 26.63 \\
\cline { 2 - 6 } & Gaston Berger & 42.95 & 18.29 & 13.3 & 23.95 \\
\hline
\end{tabular}

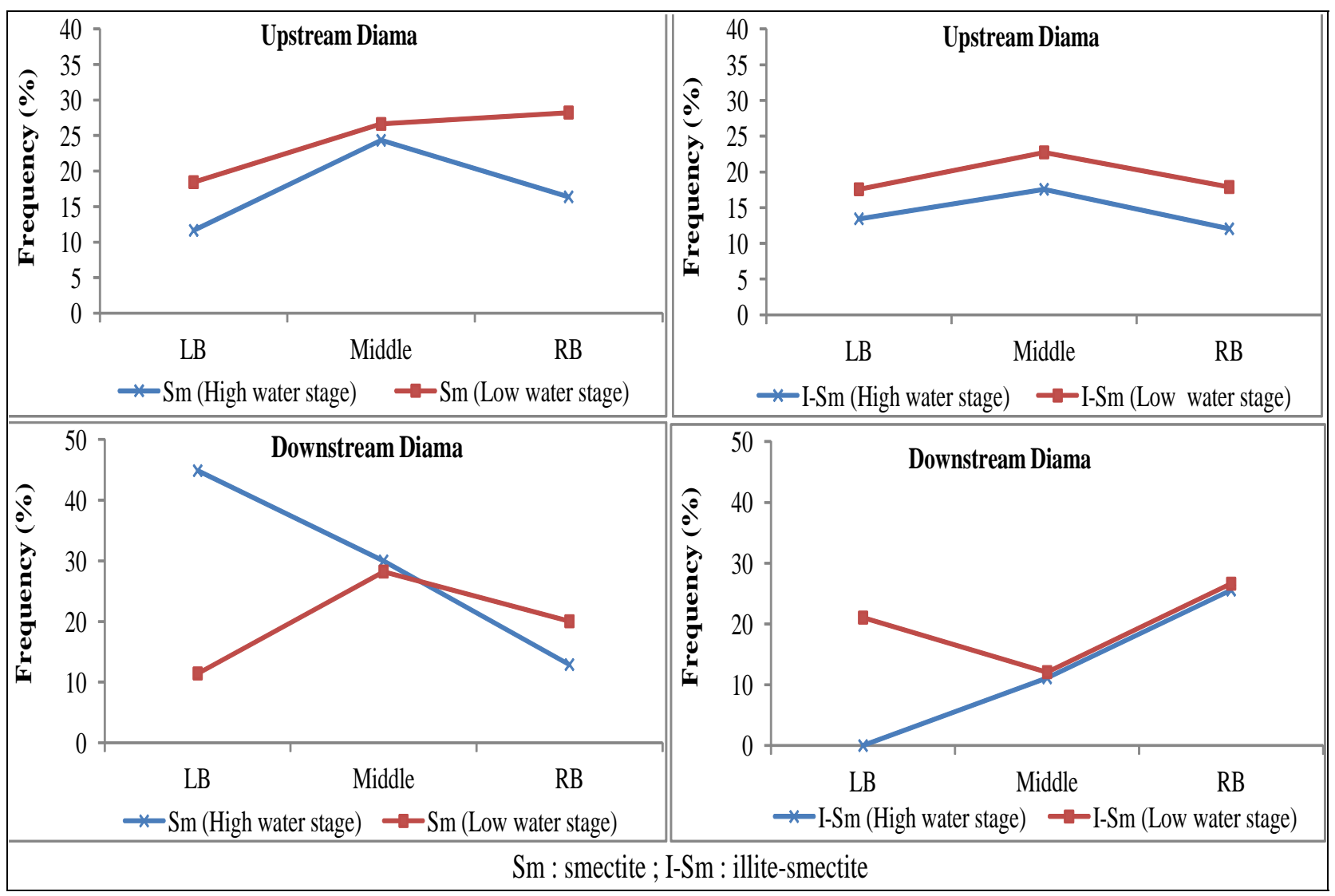

Fig. 5 Most floating clay minerals distribution according the transverse profiles upstream and downstream the dam. 
the reservoir area of the dam and tends to fade below the dam between Diama and the mouth entailling a homogeneous mineral assemblage.

\section{Discussion}

Upstream the Diama dam, clay contents are highest in the channel middle and the right bank where the water depth is more important. These features can be explained by the fact that Senegal river bathymetric profiles are commonly unsymmetrical with lower slopes on the left bank and a mid-channel shifted toward right bank (Fig. 1) and by sediments trapping during closure of dam outlets. The contents slightly decrease in the downstream dam vicinity, when outlets are opened. Outlets opening activate particles in suspension during high water stage. Towards the river mouth, clay fraction progressively decreases and tends to be reduced in the sediments deposited at the mouth. In fact, the low transport energy towards ocean probably tends to lower clay contents in sediments by facilitating their sedimentation far upstream ; but this lowering is less pronounced in the middle channel and right bank where water depth is more important comparing to the left bank probably related to the channel morphology. Slow currents near the bottom described by Bâ promote deposition of fine particles such as clays and explain their high contents in mid-channel [14]. These features seem to correspond to an original process of anthropogenic estuary compared to normal estuary where clay contents increase in the banks [16]. During the eight months low stage water, when the dam outlets are closed, suspended materials tend to settle progressively and consequently clay fraction increases in the channel middle. Thus, the downstream reach of the river acts as a sedimentation basin where accumulation increases with the water depth. With regard to these processes, clay sediments will be mostly deposited and will not reach downstream zones close to the mouth. It was also found that kaolonite and smectite represent as much as $80 \%$ of the clay minerals in the estuary system; they are associated to a lesser extent of illite and interstratified illite-smectite. Kaolinite always dominates (40\%-50\%) within the estuary domain. They are derived from ferralitic weathering of the "Salum Formation" ferruginous crust. The clay minerals composition is similar to that described in the basin formations as well as in the suspension sediments prior to dam implementation [4-6, 8]. Kane [2] showed as well a similar composition occurring just after the dam building, clay fraction in which kaolinite and smectite may constitute up to $90 \%$ of the minerals assemblage.

The clay minerals formed in this context may be transported in the sedimentary basin where they undergo selective sorting based on their physical characteristics such spherical form, density and flocculation properties. This observation has been made through works of many authors compiled in the text book of Chamley, where it was demonstrated that the first minerals which deposited are chlorite and illite, followed by kaolinite then smectite [16-19]. The fact that smectite mineral deposited lately is mainly due to its small size and low density inferred by the presence of interlayered water molecules. This is also the case of the interstratified illite-smectite clay type which generally consists of small flocky aggregates with diffuse edges and their specific flocculation characteristics induced by the saline water environment [20].

Thus, this study carried out 15 years after the dam building has demonstrated that clay minerals sedimentation process in the downstream region are characterized by reworking and homogenization of minerals which affect assemblage of clay types. The most floating minerals (illite-smectite and smectite) are concentrated in the mid-channel with higher contents during low water period. Further in the downstream region, with increase transport length and sedimentation time, the mineral sorting tends to reduce towards river mouth at the exception of few points (in the middle channel and right bank) where 
water depth is higher. On the other hand, upstream where the hydrodynamic conditions remain quiet during a long part of the year, sorting is more evident related to clays physical characteristics. In the particular case of smectite, its high contents upstream of the dam, hydrodynamically quieter, seem to confirm Brockamp and Zuther showing that agitated environment decrease levels of this mineral in the sediments [21]. Its deposit during this period could result from differential flocculation [22].

\section{Conclusion}

Sediment fine fraction $(<50 \mu \mathrm{m})$ sampled in the Senegal river estuary, 15 years after Diama dam building, showed a downstream decreasing trend of the clay fraction $(<2 \mu \mathrm{m})$. In the immediate upstream dam region, contents as high as $60 \%$ of the sediments occur in the middle channel, which decrease slightly to $50 \%$ downstream the dam. This decreasing trend continues downstream the estuary and probably becomes trivial near the river mouth. However according to the seasonal river regime, the sediment clay fraction increases during low water stage more particularly in the middle channel.

Mineralogical investigation showed that clay fraction is mainly composed of kaolinite, smectite, illite and interstratified illite-smectite with the first two representing up to $80 \%$. However, the kaolinite dominates in all seasons with contents as much as $40 \%-50 \%$. In the upstream dam zone, a hydro-sedimentary selection sorts the most floating clay minerals (smectite and illite-smectite); these clay types are more abundant in the middle channel and increase in contents during low stage water. In the downstream zone toward the river mouth, this sorting occurs only a few sites (middle channel and right bank), where water depth is high. Despite that, in most of the estuary zone, this sorting trends to be wiped out due to successive sediments reworking which leads progressively to complete homogenization of the minerals assemblage towards the river mouth.

\section{References}

[1] Barusseau, J. P., Descamps, C., Diouf, B., Kane, A. et Saos, J. L. 1993. "Processus Hydro et Morphosédimentaires et Stabilité de la Façade du Delta du Sénégal.” In. Projet CAMPUS: L’Après barrage dans la vallée du Sénégal. Rapp. Synth., Perpignan, 83-99.

[2] Kane, A. 1997. "L’après-barrages Dans la Vallée du Fleuve Sénégal. Modifications Hydrologiques, Morphologiques, Géochimiques et Sédimentologiques. Conséquences sur le Milieu Naturel et les Aménagements Hydro-agricoles.” Thèse Doctorat d'Etat, Univ. Cheikh Anta Diop, 551.

[3] Ndiaye, A. 2004. "Dynamique fluviale et évolution morphosédimentaire de l'estuaire du fleuve Sénégal après la mise en eau du barrage de Diama." Thèse Doctorat de $3^{\text {ème }}$ Cycle, Univ. Cheikh Anta Diop, 108.

[4] Kalck, Y. 1978. "Evolution des Zones de Mangroves du Sénégal au Quarternaire Récent. Etudes Géologique et Géochimique.” Thèse Doctorat $3^{\text {ème }}$ Cycle, Univ. Louis Pasteur, 121.

[5] Lappartient, J. R. 1985. "Le « Continental Terminal » et le Pléistocène Ancien du Bassin Sénégalo Mauritanien. Stratigraphie, Sédimentation, Diagenèse, Altération. Reconstitution des Paléorivages au Travers des Cuirasses." Thèse Doctorat d'Etat, Univ. Aix Marseille, 294.

[6] Monteillet, J. 1988. "Environnements Sédimentaires et Paléoécologie du delta du Sénégal au Quaternaire: évolution d'un écosystème Fluvio-marin Tropical au Cours des Derniers 100000 ans." Thèse Doctorat, Univ. Perpignan, 267.

[7] Chamley, H., et Diester, Haass, L. 1982. "Effet du Déplacement de l'embouchure du Fleuve Sénégal au Quaternaire Supérieur, sur la Sédimentation de la Marge Ouest-africaine.” C. R. Acad. Sc. Paris, t. 295 sér. II, 673-5 .

[8] Gac, J. Y. et Kane, A. 1986. "Le fleuve Sénégal : Bilan Hydrologique et Flux Continenetaux de Matières Particulaires à l'embouchure.” Sci. Géol., Bull., 39, 1, 99-130.

[9] S. E. D. A. G. R. I. 1973. "Etude Hydro-agricole du Bassin du Fleuve Sénégal.” Etude pédologique, PNUD-FAO. Paris, 251.

[10] Michel, P. 1967. "Les Dépôts du Quaternaire Récent Dans la Basse Vallée du Sénégal.” Bull. IFAN, série A, $n^{\circ} 2$, 853-60.

[11] Michel, P. 1973. "Les Bassins des Fleuves Sénégal et Gambie. Etude Géomorphologique.” Thèse Doctorat d’Etat, Univ. Strasbourg. Mém. ORSTOM 63, 3 t., 752.

[12] Monciardini, C. 1965. "La Sédimentation Eocène au 
Sénégal.” Mémoire B.R.G.M ; n 43105 p., 16 pl. L ; $\mathrm{T}$.

[13] Roger, J., Noël, B. J., Barusseau, J. P., Serrano, O., Nehlig, P., and Duvail, C. 2009. Notice explicative de la carte géologique du Sénégal à 1/500 000, feuilles nord-ouest, nord-est et sud-ouest, Ministère des Mines, de l'Industrie et des PME, Direction des Mines et de la Géologie, Dakar, 61.

[14] Bâ, M. 1993. "Les Masses d'eau de la Partie Estuarienne du Fleuve Sénégal.” In: Projet CAMPUS : L’Après barrage dans la vallée du Sénégal. Rapp. Synth, Perpignan. 41-51.

[15] Sall, M. et Kane, A. 1993. "Hydrologie et Hydrodynamique Dans la Moyenne Vallée et le Delta du Sénégal.” In: Projet CAMPUS: L’Après barrage dans la vallée du Sénégal. Rapp. Synth., Perpignan, 19-27.

[16] Gibbs, P. R. 1977. "Clay Mineral Segregation in the Marine Environment.” Journal of Sedimentary Petrology 47 (1): 37-43.

[17] Whitehouse, V. G., Jeffrey L. N., and Debrecht J. D.
1960. "Differential Settling Tendancies of Clays in Minerals in Saline Waters." In: "Clays and Clay Minerals”, 7th International Conference, 1-80.

[18] Giresse, P. 1967. "Mécanismes de Répartition des Minéraux Argileux des Sédiments Marins Actuels sur le Littoral sud du Cotentin.” Marine Geology 5 (1): 61-9.

[19] Chamley, H. 1989. Clay Sedimentology, Springer, Heidelberg, 623.

[20] Gibbs, P. R., 1983. "Coagulation Rates of Clay Minerals and Natural Sediments.” Journal of Sedimentary Petrology 53: 1193-203.

[21] Brockamp, O., and Zuther, M. 2004. "Changes in Clay Minerals Content of Tidal Flat Sediments Resulting from Dike Constructions along the Lower Saxony Cast of the North Sea, Germany." Sedimentology 5 (3): 591-600.

[22] Blaise, B. 1989. “Clay-Mineral Assemblages from Late Quaternary deposits on Vancouver Island, Southwestern British Columbia, Canada.” Quaternary Research 31: 41-56. 